\title{
Mathematical modeling of maximum height of roughness profile in turning with using wiper insert geometry
}

\author{
Matematyczne modelowanie maksymalnej wysokości profilu chropowatości
} po toczeniu ostrzami z geometrią wiper

\author{
MITE TOMOV \\ MIKOLAJ KUZINOVSKI \\ PIOTR CICHOSZ \\ HUBERT SKOWRONEK *
}

DOI: 10.17814/mechanik.2016.10.353
This paper presents mathematical models for predicting the maximum height of roughness profile using a wiper insert. Identified are four characteristic cases that occur turning when used wiper insert geometry as a function of the feed $\mathrm{f}$. It also notes several inconsistencies and differences regarding the definition of wiper insert geometry.

KEYWORDS: mathematical modeling, wiper insert geometry, turning, roughness profile.

\section{Przedstawiono modele matematyczne do prognozowania mak- symalnej wysokości profilu chropowatości podczas skrawania ostrzami typu Wiper. Zidentyfikowano cztery przypadki, które pojawiają się podczas kształtowania tymi ostrzami w zależności od wartości posuwu f. Zwrócono uwagę na pewne niejasności i różnice w definiowaniu geometrii wiper. \\ SŁOWA KLUCZOWE: modelowanie matematyczne, geometria Wiper, toczenie, profil chropowatości.}

A lot of research exists $[1 \div 6]$ aiming at predicting and analyzing the surface roughness obtained using wiper insert geometry. Analyzing the geometric interpretation of the wiper insert geometry in the catalogues of Sandvik Coromant [7, 8], one notes some ambiguities. Thus, Fig. 1 and Fig. 2 present geometric interpretations of wiper insert geometry taken from two different catalogues of Sandvik Coromant.

There is a significant difference between the interpretation presented on Fig. 1 and Fig. 2 regarding the central circle with radius $r_{\varepsilon 1}$. Fig. 1 shows the circle and this helps to uniformly define the length of wiper radius $b_{s}$. Fig. 2 does not indicate the central circle with radius $r_{\varepsilon 1}$ which leaves room for ambiguities when trying to determine the length of the wiper radius $b_{s}$. Hence one may conclude that $b_{s}$ in Fig. 1 can differ from that shown on Fig. 2 . The same conclusion arises if we compare the value for $b_{s}$ in the catalogues [7] and [8] for identical finishing inserts.

This paper aims at developing mathematical models for predicting the maximum height of roughness profile (total height of profile) using wiper insert geometry as a function

\footnotetext{
* Ass. Prof. Mite Tomov, Ph.D. (mite.tomov@mf.edu.mk), Prof. Mikola Kuzinovski Ph.D. (mikolaj.kuzinovski@mf.edu.mk) - Ss. Cyril and Methodius" University in Skopje Faculty of Mechanical Engineering-Skopje, Macedonia; Prof. Piotr Cichosz Ph.D. (piotr.cichosz@pwr.edu.pl); M.Sc. Eng. Hubert Skowronek (hubert.skowronek@pwr.edu.pl) - Department of Machine Tools and Mechanical Engineering Technologies, Faculty of Mechanical Engineering Wroclaw University of Technology, Poland
}

of the feed $f$. This research uses the symbol Rt(Rz) to denote the maximum height of roughness profile.

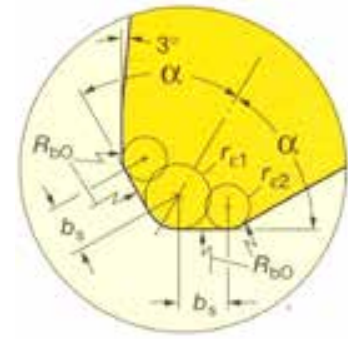

Fig. 1. Wiper insert geometry according to [7]

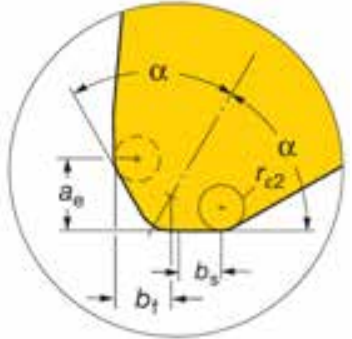

Fig. 2. Wiper insert geometry according to [8]
Mathematical models for the parameter $\operatorname{Rt}(R z)$ as a function of the feed $f$

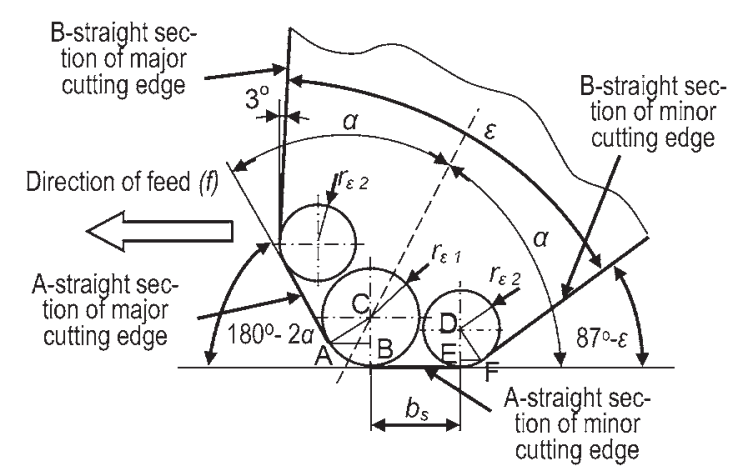

Fig. 3. Wiper insert geometry

This research makes use of the wiper insert geometry graphic interpretation shown on Fig. 3.

\section{Case 1}

The feed $f(\mathrm{~mm} / \mathrm{r})$ less than or equal to length of wiper radius $b_{s}(\mathrm{~mm})$. In the case when $f \leq b_{s}$, theoretically we get a flat surface, or:

$$
R t(R z)=0
$$

\section{Case 2}

The feed $f(\mathrm{~mm} / \mathrm{r})$ greater than the length of wiper radius $b_{s}(\mathrm{~mm})$, but only the radiuses $r_{\varepsilon 1}$ and $r_{\varepsilon 2}$ participate in the formation of roughness profile, Fig. 4. 


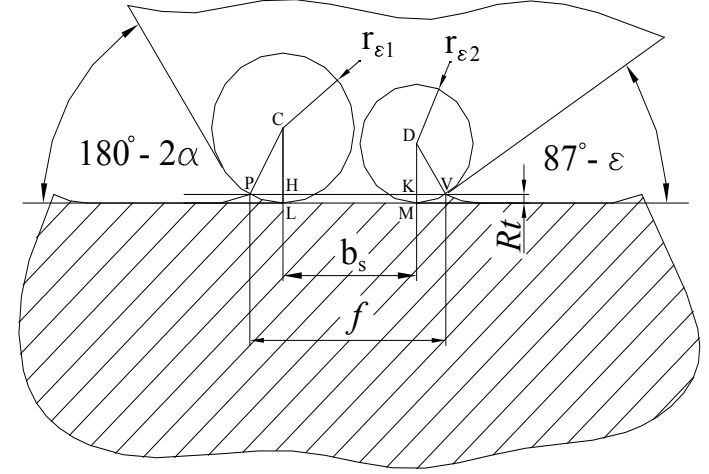

Fig. 4. Geometric interpretation of Case 2 when cutting using wiper insert geometry

$$
R t(R z)=\frac{\left(f-b_{s}\right)^{2}}{2\left(\sqrt{r_{\varepsilon 1}}+\sqrt{r_{\varepsilon 2}}\right)^{2}}
$$

\section{Case 3}

The feed $f(\mathrm{~mm} / \mathrm{r})$ greater than the length of wiper radius $b_{s}(\mathrm{~mm})$, but the radiuses $r_{\varepsilon 1}, r_{\varepsilon 2}$ and the B-straight section of the minor cutting edge participates in the formation of the roughness profile, Fig. 5 .

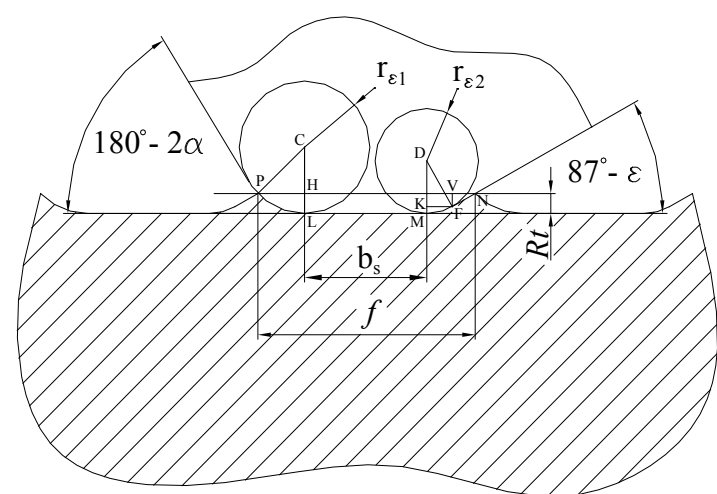

Fig. 5. Geometric interpretation of Case 3 when cutting using wiper inser geometry.

$\operatorname{Rt}(R z)=\frac{\frac{K}{\operatorname{tg}\left(87^{\circ}-\varepsilon\right)}-r_{\varepsilon 1}-\sqrt{r_{\varepsilon 1}^{2}-\frac{2 K r_{\varepsilon 1}}{\operatorname{tg}\left(87^{\circ}-\varepsilon\right)}-K^{2}}}{\frac{1}{\operatorname{tg}^{2}\left(87^{\circ}-\varepsilon\right)}+1}$

\section{Case 4}

The feed $f(\mathrm{~mm} / \mathrm{r})$ greater than the length of wiper radius $b_{s}(\mathrm{~mm})$, but the radiuses $r_{\varepsilon 1}, r_{\varepsilon 2}$, the A-straight section of the major cutting edge and the B-straight of the minor cutting edge participate in the formation of the roughness profile, Fig. 5.

\section{Conclusion}

The equations for predicting the maximum height of roughness profile when using wiper insert, suggest that the parameter $R t(R z)$ depends on a variable number of values $\left(r_{\varepsilon 1,} r_{\varepsilon 2}, b_{s,}, \varepsilon, \alpha\right)$ that participate in defining the wiper insert geometry.

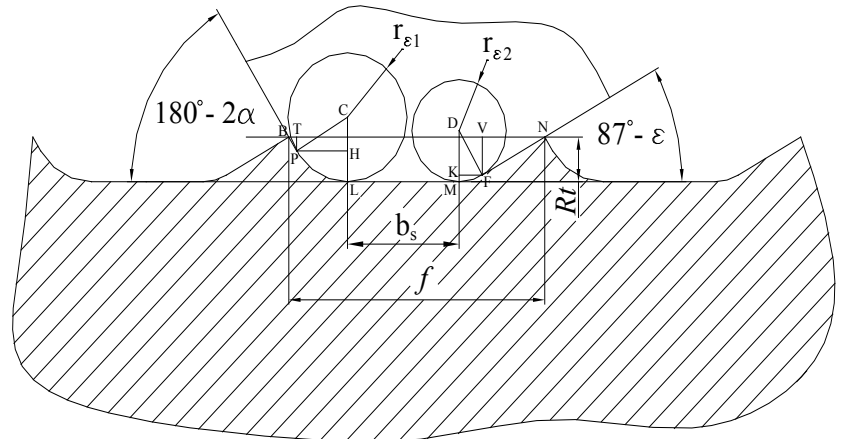

Fig. 6. Geometric interpretation of Case 4 when cutting using wiper insert geometry

$$
\begin{array}{r}
\operatorname{Rt}(R z)=\frac{f-b_{s}-r_{\varepsilon 1}\left(\sin \left(180^{\circ}-2 \alpha\right)-\frac{1-\cos \left(180^{\circ}\right.}{\operatorname{tg}\left(180^{\circ}\right.}\right.}{\frac{1}{\operatorname{tg}\left(180^{\circ}-2 \alpha\right)}+\frac{1}{\operatorname{tg}\left(87^{\circ}-\varepsilon\right)}} \\
-\frac{r_{\varepsilon 2}\left(\sin \left(87^{\circ}-\varepsilon\right)-\frac{1-\cos \left(87^{\circ}-\varepsilon\right)}{\operatorname{tg}\left(87^{\circ}-\varepsilon\right)}\right)}{\frac{1}{\operatorname{tg}\left(180^{\circ}-2 \alpha\right)}+\frac{1}{\operatorname{tg}\left(87^{\circ}-\varepsilon\right)}}
\end{array}
$$

Thus, in Case 2, Rt(Rz) directly depends on the feed $f$, the length of wiper radius $b_{s}$, and the radiuses $r_{\varepsilon 1}$ and $r_{\varepsilon 2}$. In addition to the values $\left(r_{\varepsilon 1}, r_{\varepsilon 2}, b_{s}\right)$ of Case 2 , we also have the angle $\varepsilon$ in Case 3 and the angle $\alpha$ in case 4 . Case 1 presents an interesting analysis. This usually occurs during finishing. Theoretically, if the feed $f$ is less than $b_{s}$ then the surface roughness prediction model based on the kinematical-geometrical copying of the cutting tool onto the machined surface loses its significance since it yields an ideally flat surface which cannot happen in practice [2].

The lack of information in the currently available catalogues of Sandvik Coromant about the value of the radius $r_{\varepsilon 1}$ represents a deficiency of the experimental verification of the proposed models (1), (2), (3) and (4).

\section{REFERENCES}

1. Cichosz P., Kołodziej M., Kowalski M. „Kształtowanie warstwy wierzchniej przedmiotów obrabianych ostrzami typu Wiper". Obróbka skrawaniem wysoka produktywność. Oficyna Wydawnicza Politechniki Wro-

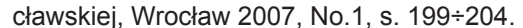

2. Karolczak P., Kowalski M. "Influence of use of wiper blades upon surface roughness in machining of austenitic stainless steel". Progressive and innovative technology and manufacturing techniques, 5.-7.9.2012, Papradno, 5-9.

3. D'Addona D.M., Raykar S.J. "Analysis of surface roughness in hard turn-

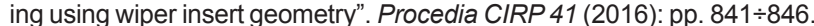

4. Özel T., Karpat Y., Figueria L., Davim J.P. "Modeling of surface finish and tool flank wear in turning of AISI D2 steel with ceramic wiper inserts". Journal of Materials Processing Technology 189 (2007): pp. $192 \div 198$

5. Abbas A.T.M. "Comparative assessment of wiper and conventional carbide inserts on surface roughness in the turning of high strength steel". Journal of Materials Science Research. Vol. 5, No. 1; 2016: pp. $32 \div 45$.

6. Özel T., Correia A.E., Davim J.P. „Neural network process modeling for turning of steel parts using conventional and wiper inserts”. Int. J. Materials and Product Technology. Vol. 35, No. 1/2, 2009: pp. 246 $\div 258$.

7. SANDVIK COROMANT. "Metalworking products, Turning tools". 2000.

8. SANDVIK COROMANT. „Poradnik obróbki skrawaniem”. 2005.

9. ISO 4287:1997. Geometrical Product Specifications (GPS) - Surface texture: Profile method - Terms, definitions and surface texture parameters. 